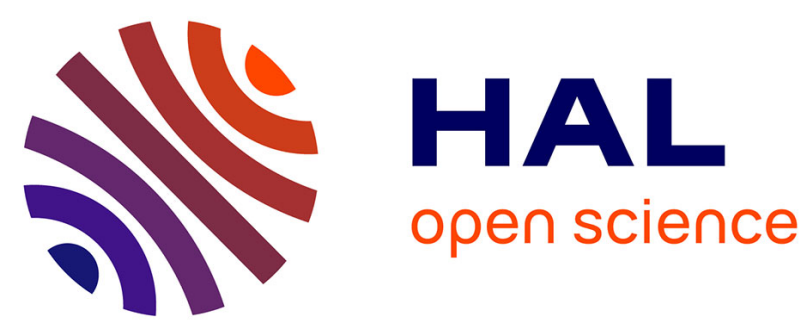

\title{
Viscous roots of active seismogenic faults revealed by geologic slip rate variations
}

P.A. Cowie, C.H. Scholz, G.P. Roberts, G.P. Faure Walker, Philippe Steer

\section{To cite this version:}

P.A. Cowie, C.H. Scholz, G.P. Roberts, G.P. Faure Walker, Philippe Steer. Viscous roots of active seismogenic faults revealed by geologic slip rate variations. Nature Geoscience, 2013, 6, pp.1036-1040. 10.1038/NGEO1991 . insu-00913173

\section{HAL Id: insu-00913173 \\ https://hal-insu.archives-ouvertes.fr/insu-00913173}

Submitted on 8 Jul 2014

HAL is a multi-disciplinary open access archive for the deposit and dissemination of scientific research documents, whether they are published or not. The documents may come from teaching and research institutions in France or abroad, or from public or private research centers.
L'archive ouverte pluridisciplinaire HAL, est destinée au dépôt et à la diffusion de documents scientifiques de niveau recherche, publiés ou non, émanant des établissements d'enseignement et de recherche français ou étrangers, des laboratoires publics ou privés. 
1 Viscous roots of active seismogenic faults revealed by geologic slip rate

2 variations

3 P. A. Cowie ${ }^{1}$, C. H. Scholz ${ }^{2}$, G. P. Roberts ${ }^{3}$, J. P. Faure Walker ${ }^{4}$ and P. Steer ${ }^{1,5}$

4 1. Department of Earth Science, University of Bergen, Bergen 5002, Norway

5 2. Lamont Doherty Earth Observatory of Columbia University, Palisades, NY 10964-8000, USA

6 3. School of Earth Sciences, Birkbeck College, University of London, WC1E 7HX, UK

7 4. Institute for Risk and Disaster Reduction, University College London, London, WC1E 6BT, UK

8 5. Géosciences Rennes, Université de Rennes 1, CNRS, Rennes Cedex CS 35042, France.

9 During the earthquake cycle viscous flow at depth contributes to elastic strain

10 accumulation along seismogenic faults ${ }^{1}$. Evaluating the importance of this contribution

11 to fault loading is hampered by uncertainty about whether viscous deformation mainly

12 occurs in shear zones or by distributed flow. Furthermore, viscous strain rate has a

13 power-law dependence on applied stress ${ }^{2}$ but few estimates exist for the power-law

14 exponent applicable to the long term in situ behaviour of active faults. Here we show

15 that measurements of topography and whole-Holocene offsets along seismically active

16 normal faults in the Italian Apennines can be used to derive a relationship between

17 stress and strain rate (averaged over $15 \pm 3$ kyrs). This relationship, which follows a welldefined power-law with an exponent in the range 3.0-3.3 $(1 \sigma)$, is used to infer the rheological structure of the crust and constrain the width of active extension across the Apennines. Our result supports the idea that the irregular, stick-slip movement of upper crustal faults, and hence earthquake recurrence, are controlled by down-dip viscous flow in shear zones over multiple earthquake cycles. 
24 because below this depth temperature- and time-dependent creep (aseismic) deformation

25 processes become progressively more important. It is therefore generally accepted that the

26 upper crustal, seismogenic, portion of a fault is rooted down dip into a ductile (mylonitic)

27 shear zone and that the transition from frictional stick-slip to viscous flow is temperature and

28 strain rate dependent. At sufficiently high temperatures, distributed ductile deformation may

29 also occur in the lower crust and upper mantle. Both localised flow in shear zones and

30 distributed flow lead to elastic strain accumulation in the upper crust and thus loading of

31 faults to failure but currently there is disagreement as to which dominates ${ }^{\mathbf{3}, \mathbf{4}}$. Experimental

32 work, field data and theory indicate the flow law for the lithosphere at tectonic strain rates

33 should be that of dislocation creep in which strain rate, $\dot{e}$, is proportional to stress raised to an

34 exponent $n$, where $n$ is typically in the range 2 to $4^{5,6}$ :

$$
\begin{array}{ll}
\dot{e}=A \sigma^{n} \exp (-Q / R T) & \text { Equation } 1
\end{array}
$$

36 Here $\sigma$ is driving stress, $A$ is a material property, $Q$ is activation energy, $R$ is the molar gas

37 constant and $T$ is absolute temperature. Geodetic observations of post-seismic relaxation

38 reveal temporal and spatial variations in effective viscosity that are most easily explained by

39 power law creep with $n \approx 3^{7}$. However geodetic data generally do not permit discrimination

40 between contributions of bulk flow of the upper mantle, of the lower crust, or plastic creep

41 within a shear zone ${ }^{2}$. Moreover, it is not clear that the rheological properties indicated by

42 postseismic transients are applicable to longer term behaviour of the coupled frictional-

43 viscous fault system ${ }^{8}$.

$44 \quad$ Here we show that extensional strain rates derived from slip on seismogenic normal

45 faults in the actively uplifting and extending central and southern Italian Apennines can be 
used to address this issue. The strain rates are measured at the surface using published structural data ${ }^{9,11}$ (Fig. 1, 2; see Methods) along active normal faults, characterised by bedrock scarps that exhibit striated fault planes and offset dated Holocene sediments and geomorphic surfaces ${ }^{11}$. These faults have developed in the last 2-3 My since thrusting in this region diminished as westward subduction of the Adriatic plate beneath the Italian peninsula slowed and slab tearing/detachment initiated $\sim 6 \mathrm{Ma}^{10,12}$. Present day topographic elevation increases inland reaching elevations up to $2900 \mathrm{~m}$ locally along the footwall crests of major extensional faults. Short wavelength $(10-20 \mathrm{~km})$ topographic variations due to faulting are superimposed on long wavelength $(100-150 \mathrm{~km})$ topography aligned NW-SE along the axis of the Italian Peninsula ${ }^{12}$ (Fig. 2a). Gravity admittance data indicate that the long wavelength topography is supported by buoyancy variations in the uppermost mantle $\mathrm{e}^{\mathbf{1 2}}$. Regional surface uplift rates ${ }^{13}$ increase in magnitude inwards from the Adriatic and Tyrrhenian coasts, mimicking in shape the long wavelength topography ${ }^{\mathbf{1 3}}$.

The extensional strain rates, averaged over the whole Holocene (15 \pm 3 kyrs), correlate with average topographic elevation along the length of the central and southern Apennines ${ }^{\mathbf{1 0}}$ (Fig. 1c). This observation is confirmed by the map view distribution of active faults relative to topographic contours (e.g., Fig. 2a). Geodetic data also show that the highest contemporary strain rates coincide with the highest elevation area in the central Apennines ${ }^{14}$. A power law regression between the strain rate, $\dot{e}$, and elevations, $h$, (in transects $90 \mathrm{~km}$ across strike by 30 $\mathrm{km}$ wide along strike) reveals a well-defined relationship with power law exponents in the range 3.0-3.3 $(1 \sigma)$ (see Methods and Supplementary material). Data from two independent sets of $30 \mathrm{~km}$ transects show that the result is not location dependent (Fig. 1d). Varying transect width (from $5 \mathrm{~km}$ to $60 \mathrm{~km}$ ) shows that over all scales the exponent lies within the range 2.7-3.4 and 2.3-4.0 at 95\% and 99\% confidence intervals respectively. These variations 
70 in strain rate cannot be attributed to thermal structure as heat flow increases gradually from $<$

$7140 \mathrm{mWm}^{-2}$ along the Adriatic coast to $>60 \mathrm{mWm}^{-2}$ along the Tyrrhenian coast, independent

72 of elevation and distance along strike ${ }^{15}$.

To interpret our data (Fig. 1d) in terms of Equation 1 we need to demonstrate that $h$ and $\sigma$ are directly proportional. Previous workers (e.g., ref 16 ) made the connection by approximating the lithosphere as a homogeneous thin viscous sheet. However, where thicker than average crust $(40-50 \mathrm{~km})$ overlies thinned mantle lithosphere, as it does in the central and southern Apennines, the vertical velocity field is unlikely to be continuous at the scale of

78 the entire lithosphere ${ }^{17}$. Furthermore, the topography varies by 100 's of meters over wavelengths $<100 \mathrm{~km}$ in which case approximations made in the thin sheet model break down $^{18}$. To avoid making these approximations we use observational constraints to relate $h$ to $\sigma$ by noting that (1) the upper crust is at or close to the threshold for brittle failure, i.e., "at 82 yield" ${ }^{19}$ and (2) earthquake focal mechanisms and fault kinematic data along active faults 9,11 indicate that the maximum compressive stress, $\sigma_{l}$, is vertical and the least compressive stress $\sigma_{3}$ is parallel to the principal extensional strain orientation (NE-SW in Fig. 2). In an elastic-brittle upper crust at yield, $\sigma_{3}$, is directly proportional to $\sigma_{l}$, compatible with incipient frictional failure on optimally oriented planes ${ }^{20}$ (Fig. 3). Thus the differential stress is also 87 proportional to $\sigma_{l}$, e.g., $\left(\sigma_{l}-\sigma_{3}\right) \approx 2 \sigma_{l} / 3$ if Byerlee friction constants are assumed. Below the base of the seismogenic zone $\left(\sim 14-17 \mathrm{~km}\right.$ depth in this region $\left.{ }^{\mathbf{1 9}, 21}\right)$, where viscous flow dominates, differential stress is less but we assume there is no stress discontinuity across this transition over long time scales (Fig. 3). Additional topographic loads that result from surface uplift relative to sea level increase $\sigma_{1}$, and hence $\left(\sigma_{l}-\sigma_{3}\right)$, driving deformation (by a depth and temperature dependent combination of frictional slip and viscous flow; Fig. 3) such that differential stress in the upper crust is relaxed to re-establish the "at yield" condition (Fig. 
$943 \mathrm{c})$. As both frictional and viscous components of the fault system undergo the same overall strain, they operate in parallel (A, B in Fig. 3b). As long as surface uplift since extension began is proportional to elevation, $h$, which as explained in the Methods is a reasonable assumption $^{\mathbf{1 0 , 1 2}}$, the increase in differential stress is independent of depth and simply proportional to $\rho g h$ ( $\rho$ is crustal density; $g$ is acceleration due to gravity). This reasoning, which requires that buoyancy forces rather than plate boundary forces are the dominant control on upper crustal deformation, explains the spatial variation in regional strain rates, provides the link between the relationship shown in Fig. 1(d) and Equation 1, and thereby allows us to constrain the exponent $n \approx 3$. Other studies that compare topography with strain rates derived from fault slip and geodetic data ${ }^{16}$ assume $n \approx 3$ to explain their data but here, for the first time, we use such data to constrain its value.

Our surface strain rate measurements are derived from slip along faults so they do not represent deformation of a continuum. For example, at the scale of individual fault blocks (20km x 20km; Fig. 2a) the spatial gradients in strain rate and mean elevation (Fig. 2b) covary, consistent with the regional relationship (Fig. 1), but the correlation between $\dot{e}$ and $h$ is poor $\left(\mathrm{R}^{2}<0.5\right)$ because of the heterogeneous pattern of brittle faulting. However, is viscous deformation at depth also likely to be heterogeneous, as proposed in Fig. 3(a)? Deforming non-linear viscous materials (i.e. $n>1$ ), in general, show a tendency to localise strain and the development of a brittle fault up-dip provides a geometrical discontinuity that influences

113 where in the viscous regime localisation preferentially develops ${ }^{22}$. Brittle-frictional faults extending down to depths of at least $10 \mathrm{~km}$ in this area are revealed by earthquake aftershocks $^{21}$. During major earthquakes, cataclasis, hydrous alteration and shear heating together contribute to grain size reduction and material weakening ${ }^{\mathbf{8}}$, processes associated with

117 localisation at the frictional-viscous transition ${ }^{23}$ (Fig. 3) and enhanced shear zone 
118 development within the viscous regime down-dip of seismogenic faults ${ }^{24}$. We also know that

119 fine grained, poly-mineralic, mylonitic shear zones remain weaker ${ }^{23}$ and deform at higher

120 strain rates than surrounding coarser grained less deformed rock (red line, Fig. 3a) and

121 contribute to lowering the effective viscosity (Fig. 1d) ${ }^{25}$.

122 In the mid- to lower crust quartzo-feldspathic mylonites form a fabric of mineral

123 segregated layers parallel to shear so that their strength is controlled by the weakest phase:

124 quartz. Using a flow law for wet quartz calibrated for mylonitic rocks ${ }^{26}$ to fit measured strain

125 rates across brittle fault zones $(\sim 5 \mathrm{~km} \text { wide })^{9}$, we estimate a lower bound on the temperature,

$126 T$, of the viscously deforming material to be $710 \pm 120 \mathrm{~K}\left(\sim 440 \pm 120^{\circ} \mathrm{C}\right)$. These temperatures

127 are reached just below the base of the seismogenic zone $(25 \pm 7.5 \mathrm{~km})$, as constrained by

128 surface heat flow data ${ }^{15}$ and upper crustal seismicity ${ }^{19,21}$ (see Methods). At the $99 \%$

129 confidence level the exponent we derive is consistent with this flow law (Fig. 1d) as well as

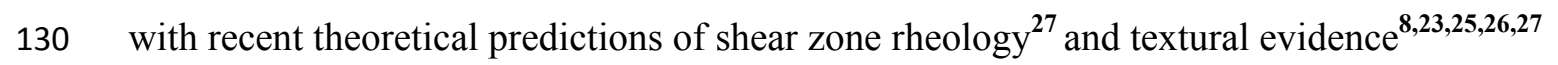

131 from poly-mineralic mylonitic rocks. We suggest therefore that the rate of viscous flow in

132 shear zones dominates over distributed flow within the lower crust and/or upper mantle and

133 regulates the slip rate we measure over long timescales on the up-dip seismogenic part of the

134 fault even if on shorter time scales rupture depends on elastic loading and mechanical

135 instabilities ${ }^{3,4}$.

136 The relationship between $\dot{e}$ and $h$ (Fig. 1d) also permits the controls on regional

137 seismic hazard to be re-evaluated. Uplift of the Italian Peninsula has been on-going since at

138 least the Quaternary, fast enough in places to raise Plio-Pleistocene marine sediments by over

$139400 \mathrm{~m}$ since the Early Pleistocene $\mathrm{e}^{\mathbf{1 0 , 2 8 , 2 9}}$. Contemporary surface uplift, documented by

140 geodetic levelling lines across both the footwalls and hanging-walls of active faults, indicates

141 regional uplift of $0-0.5 \mathrm{~mm} / \mathrm{yr}$ close to the coasts, increasing to $1.0-1.5 \mathrm{~mm} / \mathrm{yr}$ inland ${ }^{13}$. 
142 Furthermore, slip rates along the largest normal faults in the highest elevation areas of central

143 Italy (Fig. 2a) increased significantly $\sim 0.8-1 \mathrm{Ma}^{30}$. Some hanging-wall basins became

144 internally drained ${ }^{\mathbf{1 2}}$ in part because of high rates on basin-bounding faults, consistent with

145 progressive strain localisation ${ }^{\mathbf{1 4 3 0}}$. Although recent analysis of geodetic data and instrumental

146 seismicity suggests that active deformation may be localised in a zone only $\sim 50 \mathrm{~km}$ wide ${ }^{\mathbf{1 4}}$

147 (Fig. 4), historical earthquake shaking records (since 1349 A.D.) and the distribution of

148 Holocene scarps imply a broader active zone 80-90km wide (Fig. 4). These apparently

149 contradictory observations become consistent when viewed in the light of the derived

150 relationship (Fig. 1d) as it predicts that strain rate decreases rapidly across strike from the

151 highest elevation areas towards the coast (Fig. 4) and smaller strains are more readily

152 resolved when observed over a longer period of observation $\left(10^{2}-10^{4} \mathrm{yr}\right.$ versus $<10^{1} \mathrm{yr}$ in

153 this case).

In summary, rates of seismicity on frictional faults in this example are regulated by

rates of localised viscous flow at depth constrained for the first time by observations averaged over the timescale of multiple earthquake cycles and likely representing the in situ and longterm $\left(10^{4}\right.$ years $)$ mechanical properties of deforming mylonitic shear zones.

\section{Methods:}

Strain rate calculation: Reference 9 presents the calculations used to convert field measurements of the direction and amount of Holocene fault slip (since $15 \pm 3 \mathrm{ka}$ ) into strainrates within grid cells, the dimensions of which can be specified and thus varied. Fig. 2(a) shows principal extensional strain rates (blue bars) calculated using this approach for $20 \mathrm{~km} \mathrm{x}$ $20 \mathrm{~km}$ grid cells for the central Apennines. The strain rate calculations follow established methods. For details see Supplementary material. To obtain the strain rate data shown in Fig. 1 the principal extensional strain rate is first calculated using a $5 \mathrm{~km} \times 5 \mathrm{~km}$ grid oriented 
NE-SW, approximately parallel to the principal strain orientation $\left(043^{\circ}-223^{\circ}\right)$, extending a distance $90 \mathrm{~km}$ across strike. From these data we calculate the strain rate in adjacent rectangular regions $5 \mathrm{~km}$ x 90km (see Fig. S1 in Supplementary material). We combine together adjacent $5 \mathrm{~km} \times 90 \mathrm{~km}$ regions to obtain independent estimates of the principal strain rate in transects of a given width $(10 \mathrm{~km}, 20 \mathrm{~km}, 30 \mathrm{~km}$ etc.; Fig. S2) over the whole study area. Transects $30 \mathrm{~km}$ wide suppress short length scale variations due to fault displacement gradients and constrain well the regional variations in strain rate along strike along the Italian Apennines from NW to SE (see Fig. S2). To characterise shorter wavelength spatial variations in strain rate and elevation across strike across the central Apennines we calculate $\Delta \dot{e} / \Delta x$ and $\Delta h / \Delta x$ (Fig. 2b), by taking the difference in strain-rate $(\Delta \dot{e})$ and mean elevation $(\Delta h)$ between adjacent $20 \mathrm{~km} \times 20 \mathrm{~km}$ cells (Fig. $2 \mathrm{a})$ along the extension direction $\left(043^{\circ}-\right.$ $223^{\circ}$ ), from $\mathrm{NE}$ to $\mathrm{SW}$, and dividing by $\Delta x=20 \mathrm{~km}$.

Topographic data and stress: To calculate elevation (Fig. 1) topographic profiles located along the centre of $5 \mathrm{~km} \times 90 \mathrm{~km}$ regions (see strain rate calculation) were constructed from SRTM 90 m DEM data using GeoMapApp. Each of the topographic data profiles are orientated NE-SW and are separated along-strike by $5 \mathrm{~km}$ intervals. Spot heights along the topographic profiles are sampled approximately every $850 \mathrm{~m}$. The $5 \mathrm{~km}$ width transects were combined to calculate the mean elevation within wider transects $(10 \mathrm{~km}, 20 \mathrm{~km}, 30 \mathrm{~km}$ etc. $)$ to derive regional elevation variations along strike. The $95 \%$ confidence intervals of the mean elevation are calculated using the assumption of a normal distribution in the topographic spot heights ${ }^{10}$. Remnants of a flat palaeolandscape, formed close to sea-level during the Pliocene and now identified at high elevations, plus preservation of uplifted marine deposits and terraces indicate that the present day topography has mainly formed since extension began ${ }^{\mathbf{1 0}}$. Subsequent erosion/deposition is minimal and many of the high elevation hanging-wall 
191 basins remain unincised ${ }^{\mathbf{1 2}}$. See Supplementary material for more details. Stress (MPa) and

192 effective viscosity $(\eta=\sigma / 2 \dot{e}$ ) (top axis in Fig. 1d) are derived using $\sigma=\rho g h$ where $\rho=2800$

$193 \mathrm{kgm}^{-3}$ and $h=$ elevation in meters.

194

195 Correlation between strain rate and elevation: Grey lines in Fig. 1d are best fit regressions

196 through data obtained by sampling mean elevation, $h$, and strain rate, $\dot{e}$, in $30 \mathrm{~km}$ wide

197 transects (90km across strike). Data from two transect positions (offset by $15 \mathrm{~km}$ ) are

198 presented to demonstrate there is no selection bias. Regressions lines (Fig. 1d) are given by: $\dot{e}$

$199=10^{-17.8} h^{3.2}$ with $\mathrm{R}^{2}=0.8(1 \sigma)$ and $\dot{e}=10^{-17.9} h^{3.3}$ with $\mathrm{R}^{2}=0.9(1 \sigma)$. The estimate of the

200 power law exponent depends on transect width; $30 \mathrm{~km}$ wide transects best constrain its value

201 (see Fig. S2). The six different transect positions at this scale yield a value of the exponent in

202 the range 3.0 to 3.3 and a pre-factor of $10^{-17.6+0.3-0.9}$. We use $\dot{e}=10^{-17.6} h^{3.2}$ in Figure 4 to

203 predict the variation in strain rate from topography.

204 Temperature-depth calculation: We use values for $Q, \log A, R$ and $n$ (Eqn. 1) from a flow

205 law for wet quartz ${ }^{26}$ and solve for the temperature $T$ that predicts strain rates of similar

206 magnitude to those measured across $5 \mathrm{~km}$ wide fault zones ${ }^{9} \cdot Q=135 \pm 15 \mathrm{~kJ} / \mathrm{mol}, \log A=$ -

$20711.2 \pm 0.6 \mathrm{MPa}^{-\mathrm{n}} / \mathrm{s}, R=8.314472 \mathrm{~m}^{2} \mathrm{~kg} \mathrm{~s}^{-2} \mathrm{~K}^{-1} \mathrm{~mol}^{-1}, n=4$. We obtain $T=710 \pm 120 \mathrm{~K}$, i.e.,

$208 \sim 440 \pm 120^{\circ} \mathrm{C}$. Average surface heat flow of $50 \mathrm{mWm}^{-2}$ in this area ${ }^{15}$ is used to derive

209 temperature versus depth through the upper crust assuming a surface temperature of $10^{\circ} \mathrm{C}$,

210 crustal heat production $=1 \times 10^{-6} \mathrm{Wm}^{-3}$ and thermal conductivity $=2.5 \mathrm{~J} \mathrm{~s}^{-1} \mathrm{~m}^{-1} \mathrm{~K}^{-1}$.

211 Following the standard approach, crustal heat production decreases exponentially with depth

212 (characteristic depth $=10 \mathrm{~km}$ ). The inferred depth range of viscous flow implied by the

213 temperature range is $25 \pm 7.5 \mathrm{~km}$, i.e., below the depth extent of upper crustal seismicity (14- 
$21417 \mathrm{~km}^{19,21}$ ). As mantle lithosphere is thinned in this region, extrapolating this temperature

215 depth profile may underestimate lower crust/upper mantle temperatures.

216

\section{References}

218 1. Thatcher, W. Nonlinear strain build up and the earthquake cycle on the San Andreas

219 Fault, J. Geophys. Res., 88, 5893-5902 (1983).

220

221

222

223

2. Bürgmann, R. \& Dresen, G. Rheology of the lower crust and upper mantle: Evidence from rock mechanics, geodesy and field observations. Ann. Rev. Earth Planet. Sci., 36, $531-567$ (2008).

3. Kenner, S. J. \& Simons, M. Temporal clustering of major earthquakes along individual faults due to post-seismic reloading, Geophys. J. Int, 160, 179-194 (2005).

4. Freed, A. M. Earthquake triggering by static, dynamic and postseismic stress transfer, Ann. Rev. Earth Planet Sci. 33, 335-367 (2005).

5. Carter, N. L. \& Tsenn, M. C. Flow properties of continental lithosphere. Tectonophysics, 136, 27-63 (1987).

6. Newman R. \& White N. The dynamics of extensional sedimentary basins: constraints from subsidence inversion, Philos. Trans. R. Soc. Lond. 357, 805-830, (1999).

7. Freed, A. M. \& Bürgmann, R. Evidence of power law flow in the Mojave Desert mantle. Nature, 430, 548-551 (2004).

8. Handy, M. R., Hirth, G. \& Bürgmann, R. Continental fault structure and rheology from the frictional viscous transition downward. In: Tectonic Faults: Agents of Change on a Dynamic Earth. (Edited by: Handy, M. R., Hirth, G. and Hovius, N.). MIT Press Cambridge Massachusetts, London, UK, pp. 139-181 (2007). 
9. Faure Walker, J.P., Roberts, G.P., Sammonds, P.R., \& Cowie, P. A. Comparison of earthquake strains over $10^{2}$ to $10^{4}$ year timescales: Insights into variability in the seismic cycle in central Apennines, Italy., J. Geophys. Res., 115, B10418, (2010).

10. Faure Walker, J. P., Roberts, G. P., Cowie, P. A., Papanikolaou, I., Michetti, A. M., Sammonds, P., Wilkinson, M., McCaffrey, K.J. \& R.J. Phillips, Relationship between topography and strain rate in the actively extending Italian Apennines. Earth Planet. Sci. Lett., 325/326, 76-84, (2012).

11. Roberts, G. P. \& Michetti, A. M. Spatial and temporal variations in growth rates along active normal fault systems: an example from The Lazio-Abruzzo Apennines, central Italy. J. Struct. Geol., 26, 339-376 (2004).

12. D'Agostino, N., Jackson, J., Dramis, F., Funiciello, R. Interactions between mantle upwelling, drainage evolution and active normal faulting: an example from the central Apennines (Italy). Geophys. J. Int. 147, 475-497 (2001).

13. D'Anastasio, E., De Martini, P.M., Selvaggi, G., Pantosti, D., Marchioni, A. \& Maseroli, R. Short-term vertical velocity field in the Apennines (Italy) revealed by geodetic levelling data. Tectonophysics, 418, 219-234 (2006).

14. D’Agostino, N., Mantenuto, S., D’Anastasio, E., Giuliani, R., Mattone, M., Calcaterra, M., Gambino, P., and Bonci, L. Evidence for localized active extension in the central Apennines (Italy) from global positioning system observations. Geology, 39, 291-294, (2011).

15. Della Vedova, B., Bellani, S., Pellis G. \& Squarci, P. Deep temperatures and surface heat flow distribution, in Anatomy of an Orogen: The Apennines and adjacent Mediterranean Basins (eds. G. B. Vai \& I. P. Martini). Kluwer Academic Publishers. pp. $65-76$ (2001). 16. England, P. \& Molnar, P. Late Quaternary to decadal velocity fields in Asia. J. Geophys. Res., 110, B12401 (2005). 
17. Flesch, L. \& Bendick, R. The relationship between surface kinematics and deformation of the whole lithosphere. Geology, 40, 711-714 (2012).

18. Naliboff, J. B., Lithgow-Bertolloni, C., Ruff, L. J. \& de Koker, N. The effects of lithospheric thickness and density structure on Earth's stress field. Geophys. J. Int., 188, $1-17(2008)$.

19. Boncio, P., Tinari, D. P., Lavecchia, G., Visini, F. \& Milana, G. The instrumental seismicity of the Abruzzo Region in Central Italy (1981-2003): seismotectonic implications, Ital.J.Geosci. (Boll.Soc.Geol.It.), 128, 367-380, (2009).

20. Jaeger, J. C. \& Cook, N.G. Fundamentals of rock mechanics, $2^{\text {nd }}$ Edition, Chapman \& Hall, London, 593 pp. (1979).

21. Chiarabba, C. and 28 co-authors. The 2009 L'Aquila (central Italy) $\mathrm{M}_{\mathrm{w}} 6.3$ earthquake: Main shock and aftershocks. Geophys. Res. Let., 36, L18308 (2009).

22. Huismans, R.S. \& Beaumont, C. Roles of lithospheric strain softening and heterogeneity in determining the geometry of rifts and continental margins, In Karner, G.D., Manatschal, G., \& Pinhiero, L.M. (eds) Imaging, Mapping and Modelling Continental Lithosphere Extension and Breakup, pp. 107-134. Geol. Soc. Lond. Spec. Pub., 282, (2007).

23. Fusseis, F., Handy, M. R. \& Schrank. Networking of shear zones at the brittle-to-viscous transition (Cap de Creus, NE Spain), J. Struct. Geol., 28, 1228-1243 (2006).

24. Ellis, S. \& Stöckhert, B. Imposed strain localization in the lower crust on seismic timescales, Earth Planets Space, 56, 1103-1109, (2004).

25. Mehl, L. \& Hirth, G. Plagioclase recrystallization and preferred orientation in layered mylonites: Evaluation of flow laws for the lower crust, J. Geophys. Res., 113, B05202, (2008). 
300

26. Hirth, G., Teyssier, C. \& Dunlap, W.J. An evaluation of quartzite flow laws based on comparisons between experimentally and naturally deformed rocks, Int. J. Earth Sci., (Geologishe Rundschau), 90, 77-87 (2001).

27. Platt, J. P. \& Behr, W. M. Grainsize evolution in ductile shear zones: Implications for strain localisation and the strength of the lithosphere. J. Struct. Geol., 33, 537-550 (2011).

28. Gliozzi, E. \& Mazzini, I. Paleoenvironmental analysis of Early Pleistocene brackish marshes in the Rieti and Tiberino intraappenninic basins (Latium and Umbria, Italy) using ostracods (Crustacea). Palaeogeogr. Palaeoclimatol. Palaeoecol. 140, 325-333 (1998).

29. Mancini, M. D’Anastasio, E., Barbieri, M. \& De Martini, P-M. Geomorphological, paleontological and ${ }^{87} \mathrm{Sr} /{ }^{86} \mathrm{Sr}$ isotope analyses of early Pleistocene paleoshorelines to define the uplift of Central Apennines (Italy). Quaternary Research, 67, 487-501 (2007).

30. Roberts, G. P., Michetti, A., Cowie, P. A., Morewood, N. C. \& Papanikolaou, I. Fault Slip-Rate Variations During Crustal-Scale Strain Localisation, Central Italy. Geophys. Res. Lett., 29, 1168, (2002).

\section{Supplementary Information:}

Section 1: Summary of main calculation steps used in strain rate calculations plus evaluation of sources and magnitudes of uncertainties.

Section 2: Estimate of power law exponent relating strain rate to elevation using different transect widths and positions including an analysis of confidence intervals on these estimates.

Section 3: Comparing depth extent of active seismicity to inferred depth of viscous flow for different values of surface heat flow measured in the Italian Apennines. 
309 Correspondence and requests for materials should be addressed to P.A. Cowie

310 (patience.cowie@geo.uib.no)

311

312 Acknowledgements. N. D'Agostino supplied the long wavelength topography data used in 313 Figs. 2 and 4. This work was supported by NERC grants: NER/S/A/2006/14042,

$314 \mathrm{NE} / \mathrm{E} 01545 \mathrm{X} / 1$ and NE/I024127/1. Financial support was also provided by the Statoil Earth 315 System Modelling project (P.S.) and the Statoil-University of Bergen Akademia agreement 316 (P.C.). We thank R. Huismans for useful discussions and P. Molnar, M. Handy and an 317 anonymous reviewer for their comments. JFW performed the strain rate calculations and quantified data uncertainties. 
Figure 1. Correlation between Holocene-averaged regional extensional strain rates and mean elevation along the Italian Apennines. (a) Location map, (b) fault pattern overlying SRTM DEM, (c) strain rate (red) and elevation (black) versus distance measured every $10 \mathrm{~km}$ in $90 \mathrm{~km}$ transects across strike. Shading indicates $1 \sigma$ error. (d) Log-log plot of $h$, stress (MPa), effective viscosity $(\eta=\sigma / 2 \dot{e})$, versus $\dot{e}$ for two independent data sets (triangles, diamonds), offset by $15 \mathrm{~km}$ along strike, using $30 \mathrm{~km}$ wide transects. Grey lines: best fit power laws ( $1 \sigma$ error). Grey dashed lines: 99\% CI for all transect widths and positions (see Supplementary material).

\section{Figure 2. Spatial variation in strain rate with elevation across the central Apennines}

(Abruzzo). (a) Pattern of normal faults (red lines) superimposed on long wavelength topography (m) (black contours). Grey shading $>800 \mathrm{~m}$. Thick red lines: faults where Holocene slip rate exceeds long term rate $^{\mathbf{3 0}}$. Holocene extensional strain rates (blue bars) in grid cells $20 \mathrm{~km}$ x $20 \mathrm{~km}$. Grid orientated parallel to principal strain axes. (b) Topographic slope vs. change in strain rate (black dots) between adjacent $20 \mathrm{~km}$ grid cells along the maximum extension orientation from NE to SW; open circles indicate where a cell contains no faults.

\section{Figure 3. Rheology and loading of a coupled frictional-viscous fault system. (a)}

Schematic fault geometry and rheological structure. FVT = Frictional-Viscous Transition.

Strain rate enhancement (red line) depends on shear zone width (5 $\mathrm{km}$ assumed here). (b)

Brittle-frictional-viscous components loaded in parallel by a driving stress that depends on elevation, $h$. Both components may deform elastically on short time scales. Frictional element A represents (collectively) the seismogenic faults, viscous element B the corresponding viscous (mylonitic) shear zones. (c) Distribution of crustal stress (and strength) at yield and the increase in differential stress, due to regional uplift, which leads to deformation. 
357 Figure 4. Contemporary strain accumulation across Abruzzo. Width of high strain rate 358 zone (along line shown in Fig. 2a) implied by geodesy ${ }^{14}$ (red arrow) (current resolution: $\dot{e} \geq 2$

$359 \times 10^{-8}$ ) versus fault scarp mapping (blue arrow) (estimated resolution: $\dot{e} \geq 5 \times 10^{-9}$ ). Strain rate 360 variation (grey line) predicted from long wavelength topography ${ }^{14}$ (thick black line) using $\dot{e}=$ $36110^{-17.6} h^{3.2}$ (see Methods). Thin black line: SRTM topography. Stars indicate locations of 362 large historical earthquakes (1915 Fucino Ms = 7.0 and 2009 L'Aquila Mw =6.3). Dashed 363 line: width of active zone inferred from earthquake shaking records since 1349. 


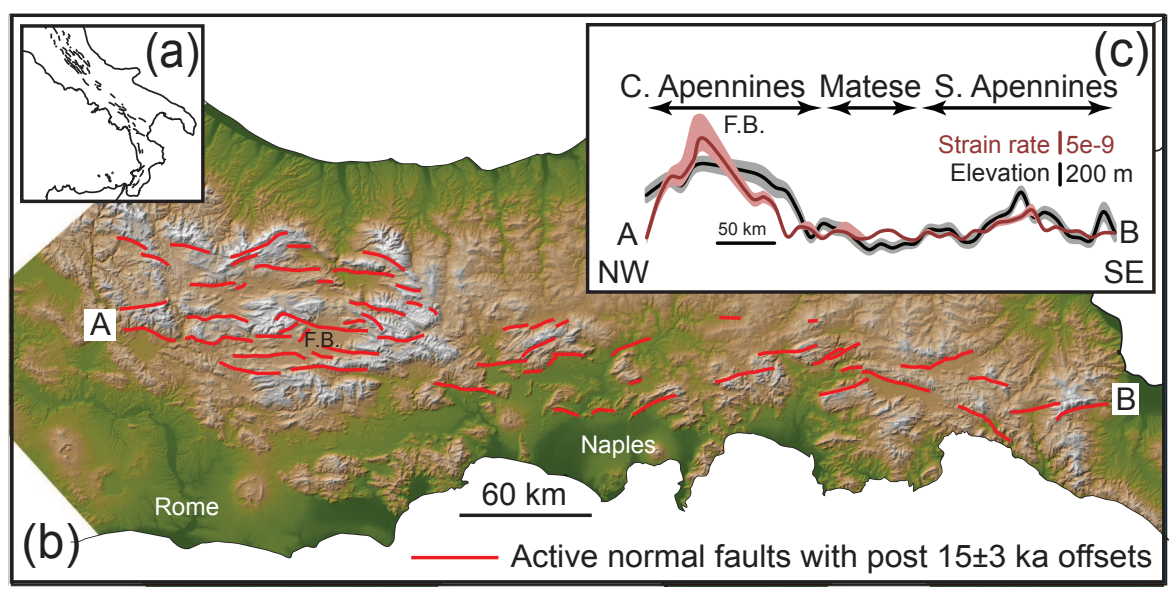

(d)

$\log _{10}$ (elevation, $\left.h, \mathrm{~m}\right)$

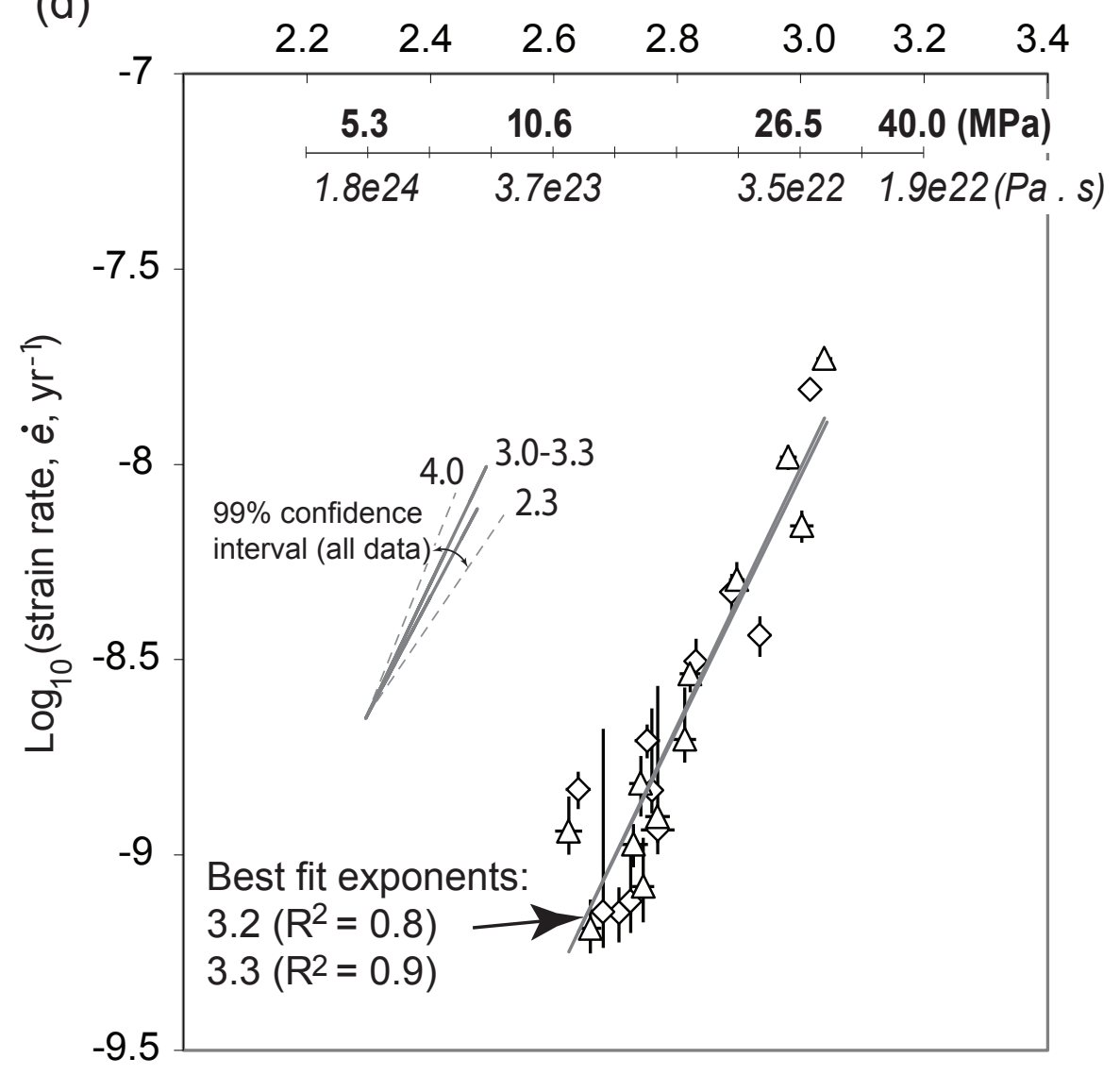




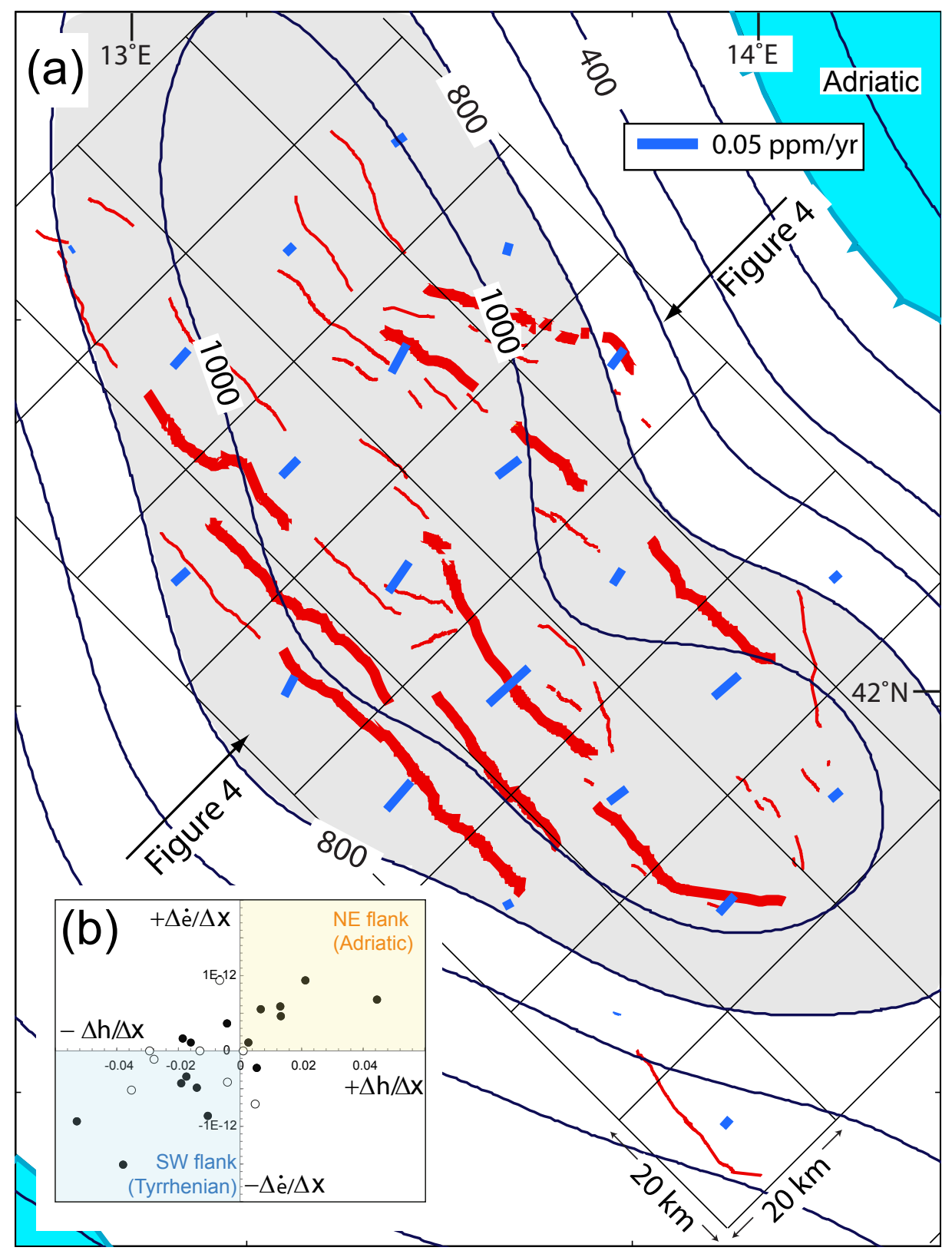

Figure 2 
(a)

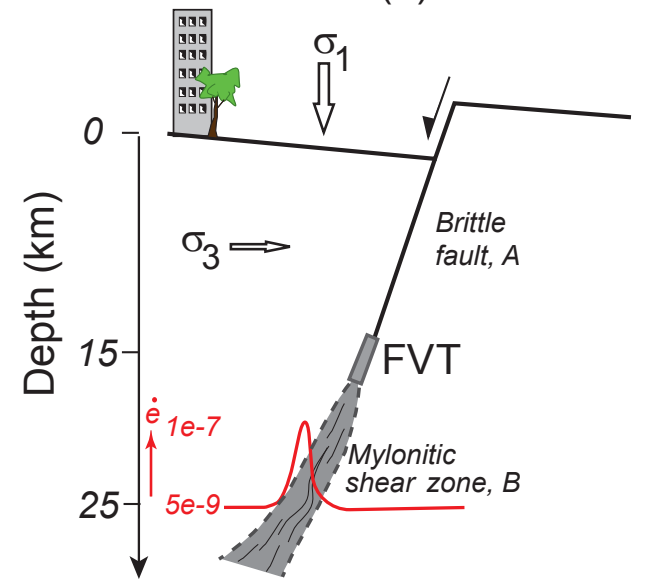

(b)

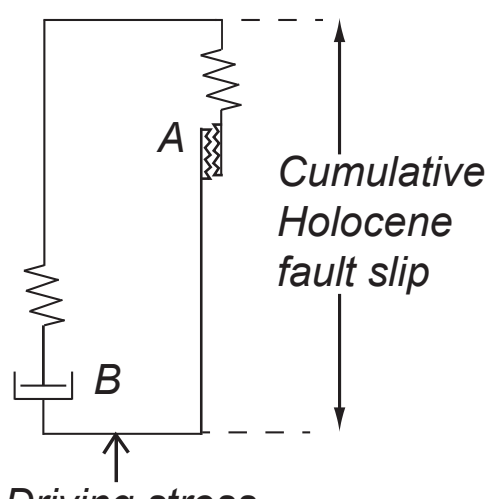

Driving stress (c)

Strength (differential stress)

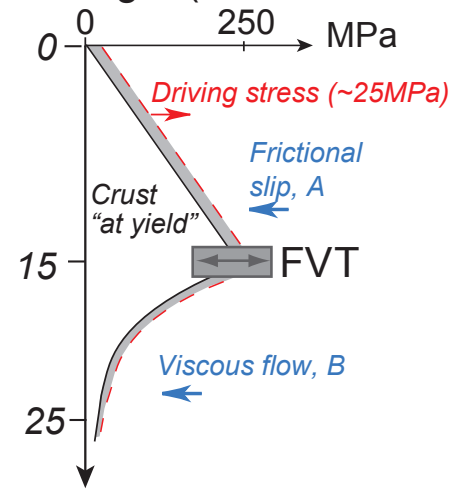

Figure 3 


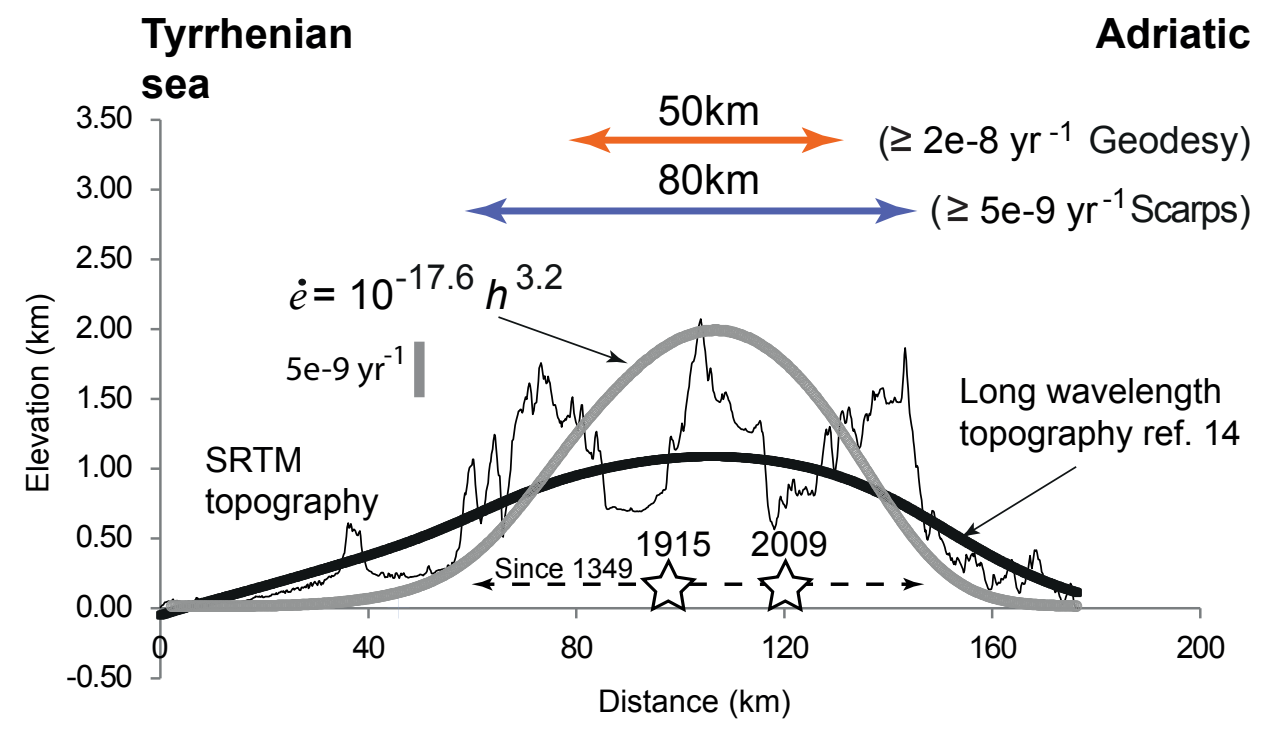

Figure 4 